\title{
Treeline dynamics with climate change at the central Nepal Himalaya
}

\author{
N. P. Gaire ${ }^{1,2}$, M. Koirala ${ }^{2}$, D. R. Bhuju ${ }^{1,2}$, and H. P. Borgaonkar ${ }^{3}$ \\ ${ }^{1}$ Faculty of Science, Nepal Academy of Science and Technology, Khumaltar, Lalitpur, GPO Box 3323, Kathmandu, Nepal \\ ${ }^{2}$ Central Department of Environmental Science, Tribhuvan University, Kathmandu, Nepal \\ ${ }^{3}$ Indian Institute of Tropical Meteorology, Pune, India \\ Correspondence to: N. P. Gaire (npgaire2007@gmail.com)
}

Received: 7 August 2013 - Published in Clim. Past Discuss.: 28 October 2013

Revised: 22 April 2014 - Accepted: 15 May 2014 - Published: 4 July 2014

\begin{abstract}
Treeline shifting in tandem with climate change has widely been reported from various parts of the world. In Nepal, several impacts of climate change on the physical environment have been observed, but study on the biological impacts is lacking. This dendrochronological study was carried out at the treeline in the high mountain slope of Kalchuman Lake (3750-4003 m a.s.1.) area of Manaslu Conservation Area in the central Nepal Himalaya to explore the impact of climate change on the treeline dynamic. Two belt transect plots (size: $20 \mathrm{~m}$ wide, $>250 \mathrm{~m}$ long) were laid which included treeline as well as tree species limit. Ecological mapping of all individuals of dominant trees Abies spectabilis and Betula utilis was done and their tree cores were collected. Stand character and age distribution revealed an occurrence of more matured B. utilis (max. age 198 years) compared to A. spectabilis (max. age 160 years). A. spectabilis contained an overwhelmingly high population ( $89 \%$ ) of younger plants ( $<50$ years) indicating its high recruitment rate. Population age structure along the elevation gradient revealed an upward shifting of $A$. spectabilis at the rate of 2.61 m year $^{-1}$ since AD 1850. The upper distribution limit of B. utilis was found to be stagnant in the past few decades. An increment in plant density as well as upward shifting in the studied treeline ecotones was observed. The temporal growth of A. spectabilis was correlated negatively with the monthly mean and minimum temperature of June to September of the current and previous year. The regeneration of A. spectabilis, on the other hand, was positively correlated with August precipitation and monthly maximum temperature of the month of the current year. The growth and regeneration of $A$. spectabilis was more sensitive to maximum and minimum temperature rather than
\end{abstract}

average temperature. The growth of the B. utilis was mainly limited by moisture stress during the pre-monsoon season. As these two species presented species-specific responses to climate change with differential pattern in regeneration condition, much wider differences are anticipated in their population status as climate continues to change throughout the century.

\section{Introduction}

During the past 100 years the global average surface temperature has increased by $0.74^{\circ} \mathrm{C} \pm 0.2^{\circ} \mathrm{C}$, and it is projected to rise by $1.4-5.8^{\circ} \mathrm{C}$ by $\mathrm{AD} 2100$ (IPCC, 2007), with the most pronounced and rapid changes at high altitudes and latitudes. However, recent studies have shown spatial and temporal heterogeneity in the past long-term temperature trend (Marcott et al., 2013; PAGES 2k Consortium, 2013). Rapid climate change has many biophysical impacts (IPCC, 2007) and already left several biological fingerprints including change in species composition of ecological communities, range and distribution shift of species as well as changes in phenology of the organisms (Parmesan and Yohe, 2003; Root et al., 2003; Parolo and Rossi, 2008; Chen et al., 2011; Gottfried et al., 2012; Kirdyanov et al., 2012; Pauli et al., 2012; Webb et al., 2012).

The high-altitude limit of forests, commonly known as treeline, timberline or forest line, represents one of the most conspicuous vegetation boundaries (Körner, 1998; Holtmeier, 2009). The position of a treeline is mainly due to strong growth limitation by low-temperature conditions 
(Körner and Paulsen, 2004; Holtmeier, 2009). Worldwide, high-altitude climatic treelines are associated with a seasonal mean ground temperature of $6.7^{\circ} \mathrm{C} \pm 0.8 \mathrm{SD}$ during the growing period (Körner and Paulsen, 2004). So, natural treeline ecotones are sensitive biomonitors of past and recent climate change and variability (Kullman, 1998), and are well suited for monitoring climate change impact (Becker et al., 2007). The high-elevation treeline is assumed to represent an ideal early-warning feature that responds to climate change positionally, structurally and compositionally (Kullman, 1998, 2001, 2007; Kirdyanov et al., 2012). Many dendroecological studies have documented that trees at the treeline often respond to climatic warming with an increase in recruitment or tree density as well as upward advances in the treeline position (Bradley and Jones, 1993; Camarero and Gutiérrez, 2004; Danby and Hik, 2007; Kullman, 2002, 2007; Batllori and Gutiérrez, 2008; Kullman and Öberg, 2009; Leonelli et al., 2011; Kirdyanov et al., 2012). A meta-analysis of a global data set, including 166 sites for which treeline dynamics had been recorded since AD 1900, showed that the treeline either advanced (52\% of sites) or remained unchanged, while only few treelines $(1 \%)$ declined under heavy anthropogenic disturbance (Harsch et al., 2009). Treelines that experienced strong winter warming and treelines with a diffuse form are more likely to advance (Harsch et al., 2009).

Himalayan ecosystems are facing the impacts of climate change. However, uncertainties about our knowledge on the relationships of Hindu Kush-Karakoram-Himalaya (HKH) treelines to other ecological conditions and processes such as carbon balance, freezing and frost, drought, soil temperature, wind, snow cover, soils, regeneration, etc. are yet to be explored (Schickhoff, 2005). Treelines from Tibet and adjacent mountainous regions have shifted very little with climate change (Liang et al., 2011; Gou et al., 2012; Lv and Zhang, 2012). However, a previous study reported an upward movement of the tree species limit due to climate change in the Himalayas (Dubey et al., 2003). High-altitude regions in the interior of the Nepal Himalaya are little affected by anthropogenic activities and may therefore provide valuable information to evaluate the isolated consequences of climate change (Cook et al., 2003).

The atmospheric temperature of Nepal has been increasing consistently after the mid-1970s with higher rate than the global average (Shrestha et al., 1999; IPCC, 2007), and the warming has been found to be even more pronounced in the high altitudes of the Nepal Himalaya (Shrestha et al., 1999; Shrestha, 2008). However, no specific trend in precipitation has been observed (Shrestha, 2008). The effect of warming temperature in the Nepal Himalaya is reflected by shrinking permafrost areas (Fukui et al., 2007) and rapidly retreating glaciers (Fujita et al., 1998; Bajaracharya et al., 2007; Bolch et al., 2012; Yao et al., 2012), among other phenomena. Impacts on biological processes including range shifting of species are also expected but scientific studies on these aspects are scarce (Schickhoff, 2005). Past works on tree rings in Nepal have identified several promising species for dendrochronological study, including Abies spectabilis and Betula utilis (Bhattacharyya et al., 1992; Cook et al., 2003; Sano et al., 2005; Dawadi et al., 2013), which can grow up to the treeline ecotone (Schickhoff, 2005; Ghimire et al., 2008). Recently, researchers from Nepal have initiated dendroecological studies covering various treeline sites of the Nepal Himalaya (Bhuju et al., 2010; Suwal, 2010; Gaire et al., 2011). However, concrete results on the treeline shifting due to climate change are yet to be explored.

The present study was carried out to (i) ascertain the present position of upper forest, treeline and species limits, (ii) characterize the stand structure and dynamics at the forest line and treeline, and (iii) analyse the response of tree growth and regeneration with climate change using both dendroecological and dendroclimatological techniques. For this study, the treeline is defined as the ecotone up to where $2 \mathrm{~m}$ tall trees can be found, and the species limit is defined as the highest position to which seedlings or saplings of the tree species are present. Treeline dynamics describe changes in the regeneration and population dynamics as well as positional change of the tree species in the treeline ecotone.

\section{Materials and methods}

\subsection{Site and species selection}

The study was carried out at Manaslu Conservation Area (MCA, area: $1663 \mathrm{~km}^{2}$ ), a high mountain protected site in the central Nepal Himalaya, established in AD 1998. MCA has a diverse natural resource base with sparse human population and is relatively inaccessible. The area includes nine bioclimatic zones ranging from the lower subtropics to the nival zone with only marginal infrastructure, such as roads. It is the least explored protected area of the country. Local people depend on agriculture, animal husbandry and utilization of natural resources for their sustenance. Buddhism has positively contributed in protecting the forest and biodiversity (Chhetri, 2009).

The study site is a mountain slope adjacent to Kalchuman Lake situated at $3690 \mathrm{~m}$ above mean sea level (a.m.s.l.). With human settlements located not more than $2500 \mathrm{~m}$ a.m.s.l., the study site is little disturbed anthropogenically. There is a dense forest in between the settlement and study sites. Soil is rich in humus, dark in colour, and its depth varies locally with the steepness of the slope. The tree canopy of the treeline ecotone is formed by A. spectabilis and B. utilis with a Rhododendron campanulatum understory and some scattered Sorbus microphylla. Above the treeline occur scrubs of Rhododendron anthopogon and some herbaceous species. The Himalayan silver fir, A. spectabilis is a tall evergreen tree endemic to the Himalaya and found between the lower temperate and lower alpine zone (2400$4400 \mathrm{~m}$ ) from Afghanistan to Bhutan (Ghimire et al., 2008). 
Similarly, B. utilis is a medium-sized deciduous tree which forms monospecific as well as mixed forests at the upper limit of the treeline (Ghimire et al., 2008).

The climate of the study area is monsoon dominated. The mean annual rainfall over the past 30 years (1980-2009) at nearby meteorological station at Chame was $967 \mathrm{~mm}$ $(\mathrm{SD}=280)$. The monthly average temperature was found to be highest in July and lowest in November (Fig. 1a). The highest recorded temperatures were $23.4^{\circ} \mathrm{C}$ during June 1998, the lowest $-4.5^{\circ} \mathrm{C}$ during January of 1999 and 2000 . Over the past 30 years, the station experienced a decreasing trend in rainfall by $3.9 \mathrm{~mm}^{2} \mathrm{yr}^{-1}\left(n=30, R^{2}=0.014\right.$, $p<0.52$ ) (Fig. 1b) and an increasing trend in mean annual temperature by $0.017^{\circ} \mathrm{C}_{\text {year }}{ }^{-1}$ (Fig. 1c). In this station monthly mean minimum temperature was decreasing while monthly mean maximum temperature was increasing significantly (Supplementary Fig. S1). Similarly, mean annual rainfall at Larke, Gorkha, was $1252 \mathrm{~mm}(\mathrm{SD}=535)$. In Larke, during the past 30 years (1980-2009) there was a significant ( $\left.n=30, R^{2}=0.26, p<0.003\right)$ decreasing trend of rainfall by $28 \mathrm{~mm}$ year $^{-1}$ (Fig. 1b). This decreasing trend is more pronounced and significant ( $p<0.0003, R^{2}=0.46, n=23$ ) after 1987 with a decrease in annual rainfall by $55 \mathrm{~mm}_{\text {year }}{ }^{-1}$ between 1987 and 2009.

\subsection{Field visit and data collection}

Field work was carried out in three expeditions: two in 2010 (May-June and September-October) and one in 2012 (October). After careful observation in transect walk at the treeline ecotone, the upper species limits of $A$. spectabilis and $B$. utilis were ascertained. Two altitudinal transect plots (20 $\mathrm{m}$ wide and $>250 \mathrm{~m}$ long), named Transect 1 (T1) and Transect 2 (T2) were marked at two sites of the treeline ecotone. The plots were oriented with their longer side parallel to the maximum slope and covered the current species limit and treeline ecotone (Fig. 2). T1 was above the continuous forest, while $\mathrm{T} 2$ was situated above the middle part of the lake. It was also assumed that the lake might hinder the dispersal of seedlings in the area. Individual plants were categorized and enumerated into three height classes: trees $(>2 \mathrm{~m})$, saplings $(0.5-2 \mathrm{~m})$ and seedlings $(<0.5 \mathrm{~m})$, following Wang et al. (2006) and Kullman (2007).

Census counts were carried out inside each plot for A. spectabilis and B. utilis. For every A. spectabilis individual, their geographic location in the plot (latitude, longitude, and altitude); size (diameter at breast height (DBH), height); growth form and internodes interval of all individuals less than $2 \mathrm{~m}$ were recorded. The age of trees was calculated by tree core analysis, while that of seedlings and saplings were estimated by counting the branch whorls and scars left along the main stem (Camarero and Gutiérrez, 2004; Wang et al., 2006; Liang et al., 2011). This age estimation was also validated by comparing it with the age obtained by the number of tree rings in the basal sections collected from the root col-
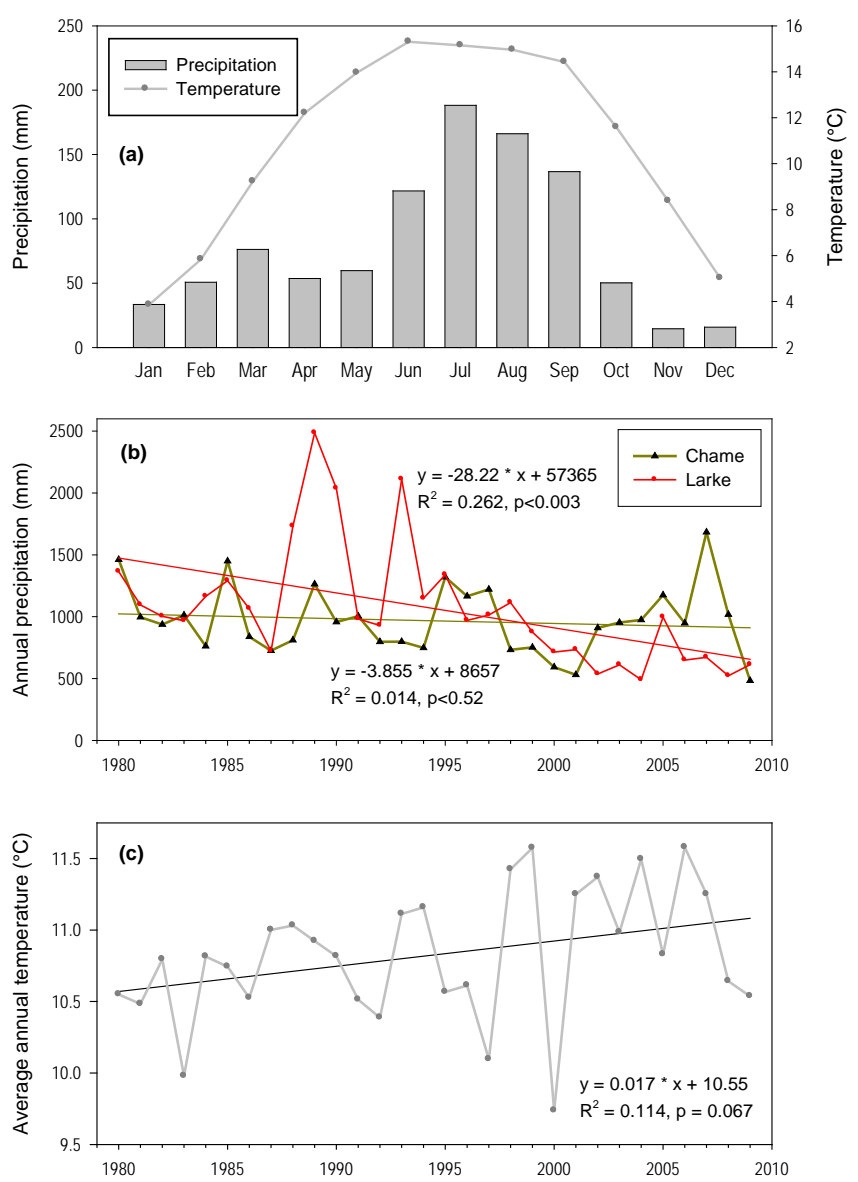

Figure 1. Climatic trend in the local stations: mean monthly (19802009) precipitation and temperature at Chame, Manang station (a); annual trend of precipitation at Larke, Gorkha and Chame (b), and trend of mean annual temperature at Chame (c).

lar of saplings and seedlings ( $n=34)$. The age estimates by whorl count and ring count correlated positively $\left(R^{2}=0.91\right.$, $P<0.0001$ ), but the internodes or whorl count ages are systematically lower by $1.57 \pm 0.33$ years (max. 4 years) in saplings and 1.27 years in seedlings. These suggest that the whorl count method can give a fairly accurate indication of the age of saplings and seedlings of conifer species like A. spectabilis.

\subsection{Tree core and cut-stump collection and analysis}

Tree cores were collected using the increment borer (Haglöf, Sweden) following the standard technique suggested by Fritts (1976) and Speer (2010). The cores were collected from the base of each and breast $(1.3 \mathrm{~m})$ height of some individuals of $A$. spectabilis and $B$. utilis in the plots. Cores were also collected from the larger $A$. spectabilis and $B$. utilis trees outside of the plots. A total of 249 cores and cut-stump samples (172 A. spectabilis and 77 B. utilis) were collected (Supplementary Table S1). Collected core and cut-stump samples 
(a)

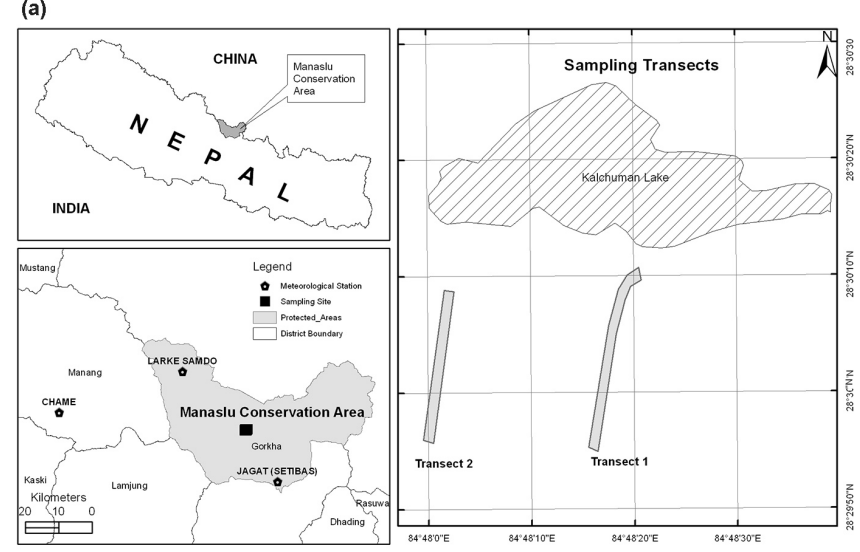

(b)

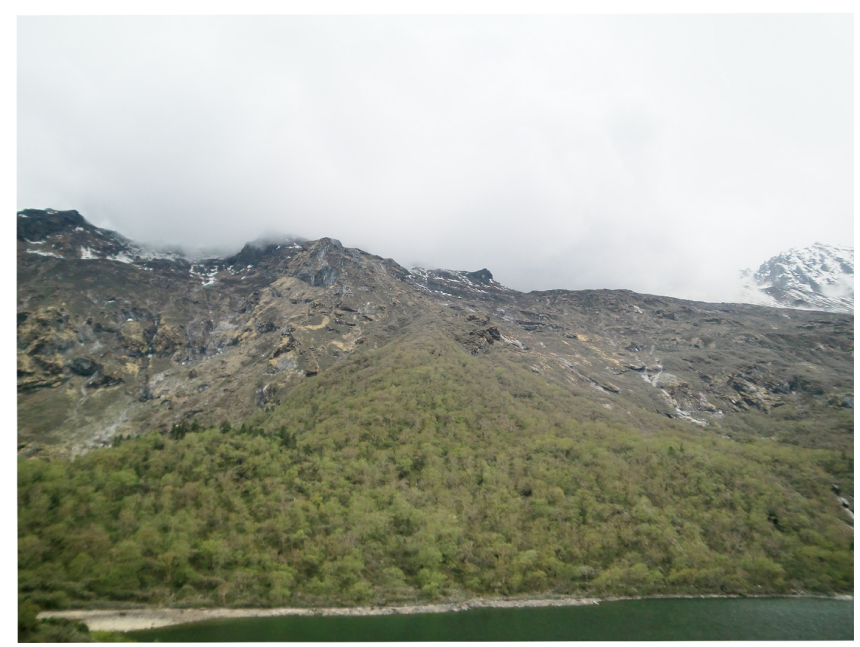

Figure 2. Location map of the study area showing the position of the study plots and local meteorological stations (a), and a photo of the study site showing treeline, species limit and some portion of Kalchuman Lake (b).

were taken to the Dendro-lab of the Nepal Academy of Science and Technology for laboratory analysis.

Collected cores were air dried, mounted, sanded and polished using successively finer grades of sand paper (1001000 grits size) until optimal surface resolution allowed annual rings to be visible under the microscope. Each ring was counted under the stereo zoom microscope and assigned a calendar year. The width of each ring was measured to the nearest $0.01 \mathrm{~mm}$ precision with the LINTAB ${ }^{\mathrm{TM}}$ measuring system attached to a PC with the TSAP Win software package (Rinn, 1996). All the tree cores were crossdated by matching patterns of relatively wide and narrow rings to account for the possibility of ring-growth anomalies such as missing or false rings or measurement error. Crossdating was done using the alignment plotting technique and also looking the math graphs. The quality of cross-dating of each sample was checked using the computer program COFECHA (Holmes, 1983).
The corrected ring-width data were standardized using the computer program ARSTAN (Cook, 1985). The ringwidth series were standardized using conventional detrending methods with appropriate options of a negative exponential, linear or cubic spline curve to each series. Each ring-width-index series was then pre-whitened using autoregressive modelling to remove any autocorrelation effects (Cook, 1987). Finally, three chronologies - namely standard, residual and ARSTAN - were prepared using the corrected sample. Various chronology statistics like mean sensitivity, standard deviation, autocorrelation, mean series correlation, signal-to-noise ratio, expressed population signal (EPS) and variance explained were calculated to assess the quality of the site chronologies. Temporal changes in the mean radial growth were assessed by doing regime shift (significant changes in mean radial growth) analysis (Rodionov, 2004). Regime shift was detected based on a statistical test whereby data are processed in time sequence and the hypothesis of a regime shift or discontinuity is tested for each new observation (Rodionov, 2004, 2006). We set the cutoff parameter at 10 years in order to detect changes in mean radial growth driven by high-frequency events and used a $95 \%$ level of significance.

\subsection{Population demography, regeneration and treeline dynamics}

The age obtained from cross-dated samples was used for demographic analysis after the necessary correction for years to core height and years to centre of missed pith. Such correction was made using age-height regression and age-diameter regression combined with the fitting of a circle template to the ring curvature so as to estimate the distance of the core to the centre (Camarero and Gutiérrez, 2004; Speer, 2010). For B. utilis cores from representative sample trees covering different diameter at breast height (DBH) classes were collected. Based on the ages of 39 Betula trees, a regression analysis model between DBH and age was established (Fig. 3), and the relationship was used to estimate the age of all $B$. utilis trees from which tree cores were not taken.

The regeneration rate was determined by age histogram using the number of seedlings, saplings and tree individuals. The treeline dynamics was analysed by density distribution of tree, sapling and seedling as well as the elevation-wise age distribution of the studied species. The upper species limit expansion was studied by observing the age of each individual in the entire plot following Camarero and Gutiérrez (2004) and Liang et al. (2011). In order to calculate the rate of species limit shift, the maximum elevation of live individuals and the position of the oldest individual within each transect was determined. Then, the species limit shift rate $\left(\mathrm{m}_{\mathrm{year}}{ }^{-1}\right.$ ) was calculated by dividing the change in species limit elevation (position) by the time elapsed. 


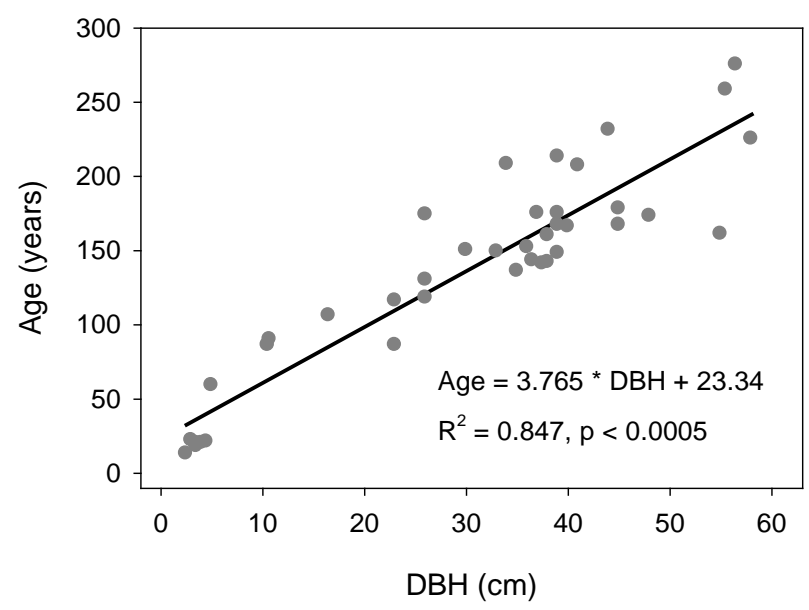

Figure 3. Diameter at breast height $(\mathrm{DBH})$ versus age of Betula utilis from the Kalchuman Lake area, Manaslu Conservation Area.

\subsection{Climatic influence on radial growth and regeneration}

Before proceeding to the response analysis of tree growth and climate, the seasonality of tree growth was defined. Field observation and tree ring data have shown that radial growth of A. spectabilis at treeline sites ceases in September-October (Sano et al., 2005). Because climate in the preceding growing season often influences tree growth in the following year (Fritts, 1976), we analysed the influence of temperature and precipitation since June of the previous growth year until October of the current growth year. Simple Pearson correlation coefficients were used to quantify relationships between treering chronologies and climate variables, i.e. monthly average $\left(T_{\text {mean }}\right)$, maximum $\left(T_{\max }\right)$ and minimum $\left(T_{\min }\right)$ temperature and total monthly precipitation. Similarly, influence of seasonal climate on radial growth was also assessed for four seasons - namely winter (December-February, DJF), premonsoon (March-May, MAM), monsoon (June-September, JJAS) and post-monsoon (October-November, ON). In addition to this, influence of annual average temperature and total precipitation was also calculated. One of the major difficulties in undertaking dendroclimatic research in Nepal relates to the paucity of long meteorological records for statistically calibrating the tree rings because most of the weather stations in Nepal were only established after 1960 for precipitation and 1970 for temperature (Bhattacharyya et al., 1992; Cook et al., 2003). Available climatic data (19802009) of the nearest stations at Chame $\left(28^{\circ} 33^{\prime} \mathrm{N}, 84^{\circ} 14^{\prime} \mathrm{E}\right.$ and $2680 \mathrm{~m}$ a.s.l.) of Manang and Larke Samdo $\left(28^{\circ} 40^{\prime} \mathrm{N}\right.$, $84^{\circ} 37^{\prime} \mathrm{E}$ and $3650 \mathrm{~m}$ a.s.l.) of Gorkha were used (Fig. 2). Missing values were replaced by average value of the same month's data.

To investigate the relationship between regeneration and climate change, recruitment or age data were summed across 5 -year intervals as the finest resolution to take into account uncertainties in age estimates and compared with monthly climate records compiled into 5-year averages over the same time period (Camarero and Gutiérrez, 1999; Wang et al., 2006). To describe the climate-recruitment relationships, monthly climatic data (mean, maximum and minimum temperatures, and total precipitation) from Chame, Jagat and Larke stations were used. Climatic factors limiting regeneration were identified from linear correlation analysis between regeneration and climatic data.

\section{Results}

\subsection{Treeline position and structural parameters}

The species limit of A. spectabilis was recorded at $3984 \mathrm{~m}$ (GPS e-Trex) in Transect 1 (T1) and $3955 \mathrm{~m}$ in Transect 2 (T2) and its treeline at $3907 \mathrm{~m}$ in T1 and $3830 \mathrm{~m}$ in T2. In the case of $B$. utilis the treeline and species limit were recorded at the same elevation in both transects, i.e. at $3996 \mathrm{~m}$ in $\mathrm{T} 1$ and $4003 \mathrm{~m}$ in $\mathrm{T} 2$.

Structural parameters (age, DBH, and basal area) revealed that both of the species were more matured in $\mathrm{T} 1$ than in T2 (Supplementary Table S2). The maximum age of A. spectabilis and B. utilis was higher in $\mathrm{T} 1$ than in $\mathrm{T} 2$. A. spectabilis tree density ranged from 50 to 280 trees ha $^{-1}$. The total basal area of $B$. utilis in both plots was higher than A. spectabilis. The DBH distribution of $A$. spectabilis showed bimodal distribution in $\mathrm{T} 1$ with peaks at $0-10 \mathrm{~cm}$ and 35 $40 \mathrm{~cm}$ DBH class (Supplementary Fig. S2). In T2, the DBH distribution of the same species had an inverse-J-shaped distribution indicating continuous regeneration in the area. DBH distribution of $B$. utilis in $\mathrm{T} 1$ presents a unimodal bell shape, indicating poor regeneration in recent years. However, DBH distribution of the same species in $\mathrm{T} 2$ indicates better recruitment of individuals. Similar trends were observed in height distribution. Age class distribution of the species was heterogeneous with an inverse-J-shaped and unimodal to multimodal bell-shaped distribution (Supplementary Fig. S3).

\subsection{Age structure, regeneration and treeline dynamics}

The demographic distribution of A. spectabilis and B. utilis revealed the recruitment and mortality pattern over time (Supplementary Fig. S3 and Fig. 4). The age distribution of A. spectabilis indicated that the species was established in the early 1850s in T1 (Fig. 4a) and in the 1950s in T2 (Fig. 4b). The population of A. spectabilis was dominated by young individuals comprising $89 \%$ of the population below 50 years age. The recruitment of $A$. spectabilis was slow in the $1850 \mathrm{~s}$, accelerating after 1950, and again after 1980 . This could be related to increased temperature in the area. The recruitment of B. utilis started from the $1820 \mathrm{~s}$ in $\mathrm{T} 1$, then reached $\mathrm{T} 2$ in the 1840s (Fig. 4a, b). The proportion of young population of $B$. utilis was low ( $13 \%$ of the population $<50$ years old) as compared to middle-aged trees ( $42 \%$ being $50-100$ years 
old) and older ones (45\% over 100 years old). Recruitment of $B$. utilis was lower at the beginning in both transects, but increased slowly to peak in the 1880 s in T1 and the 1930s in T2. Regeneration oscillated between the 1880s and 1940s and declined steadily since then.

The comparative age of the two tree species shows that the regeneration of the $B$. utilis was higher before the recruitment of A. spectabilis in the treeline community. Spatialtemporal assessment of the upper species limit distribution of $A$. spectabilis and $B$. utilis revealed that the position of B. utilis was higher than the position of A. spectabilis in both transects (Fig. 4a, b). Similarly, B. utilis colonized the area earlier than A. spectabilis. Seedlings of the A. spectabilis species were found about $80 \mathrm{~m}$ higher than trees indicating upward migration (Fig. 4c). Matured trees and young seedlings were mostly dominant at lower elevation indicating stand densification as well. T2 had a lower number of seedlings than T1. Seedlings of B. utilis were not recorded in both transects, but some were observed just outside the plots. On the basis of the temporal and spatial distribution of the ages of $B$. utilis at an elevation gradient, we calculated that the seedlings of the species were established at $3860 \mathrm{~m}$ between the 1810s and 1820s and at $3990 \mathrm{~m}$ during the $1890 \mathrm{~s}$ (Fig. 4a). The A. spectabilis on the other hand made a treeline community around 1850 at $3765 \mathrm{~m}$ and reached $3907 \mathrm{~m}$ (present A. spectabilis treeline) during the 1950s. Seedlings of this species are now established at $3984 \mathrm{~m}$, which is close to the upper limit of $B$. utilis. The average upward movement of the upper distribution limit of $A$. spectabilis at the study sites was calculated to be $2.61 \mathrm{~m}^{-1} \mathrm{rer}^{-1}$ (1.56$3.66 \mathrm{~m} \mathrm{year}^{-1}$ ). The upward shifting of A. spectabilis was more pronounced in $\mathrm{T} 2$ with migration rate of $3.66 \mathrm{~m} \mathrm{year}^{-1}$, while it was $1.56 \mathrm{~m} \mathrm{year}^{-1}$ in $\mathrm{T} 1$.

The densities of saplings and seedlings of $A$. spectabilis (Supplementary Table S3) indicated that its regeneration was higher in $\mathrm{T} 1$ than in $\mathrm{T} 2$ and also higher than that of B. utilis in both transects. As there was a presence of a large number of saplings and seedlings of $A$. spectabilis in the site but no seedlings of $B$. utilis, it is anticipated that the structure and composition of this treeline community will change in the future.

\subsection{Tree-ring chronology}

A 229-year-long (AD 1782-2010) standard tree ring chronology of A. spectabilis was prepared using 46 cores from 29 trees (Fig. 5). The chronology revealed that there was no constant increment in the growth of trees but it fluctuated through time. The years 1818, 1819, 1974 and 1999 were characterized by particularly poor growth, whereas the years 1789, 1814 and 2009 resulted in particularly wide rings. Results of the regime shift analysis suggest that there have been constant changes in mean radial growth which are dominated by short periods of above-average radial growth. Two major periods with low radial growth were 36 years start-
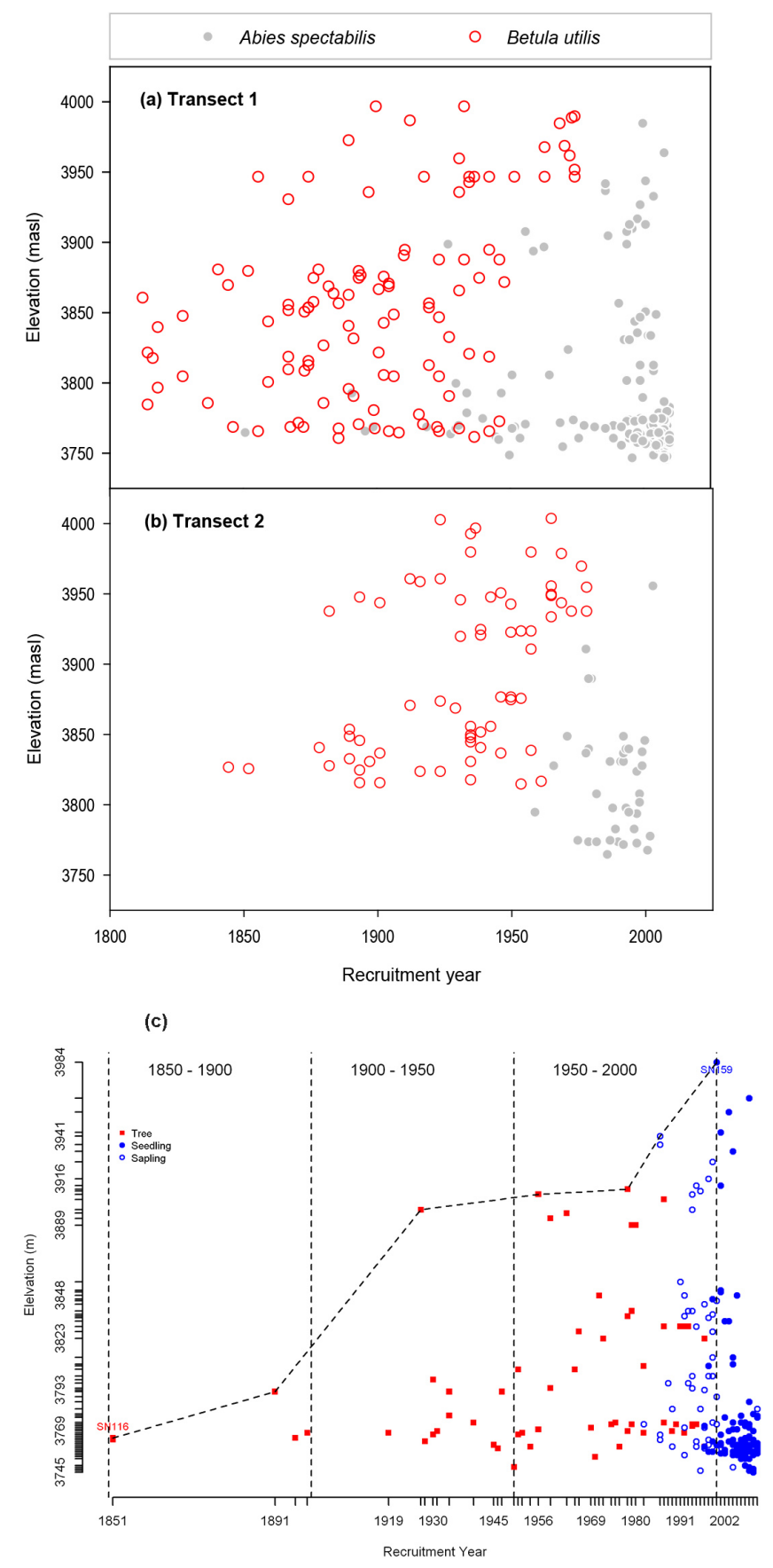

Figure 4. (a, b) Spatial and temporal variation in the recruitment of tree species in T1 and T2. (c) Temporal upward shifting of Abies spectabilis along an elevation gradient in the study site.

ing in 1854 and 63 years starting in 1940 . The period centred on 1905 is one of the shortest with below-average radial growth. In the recent period (after 2000) the radial growth is increased. Several statistics that were calculated for the time span of AD 1782-2010 and for the period of overlap (AD 1920-2005) of all tree-ring series indicated a high dendrochronological potential (Supplementary Table S4). The 


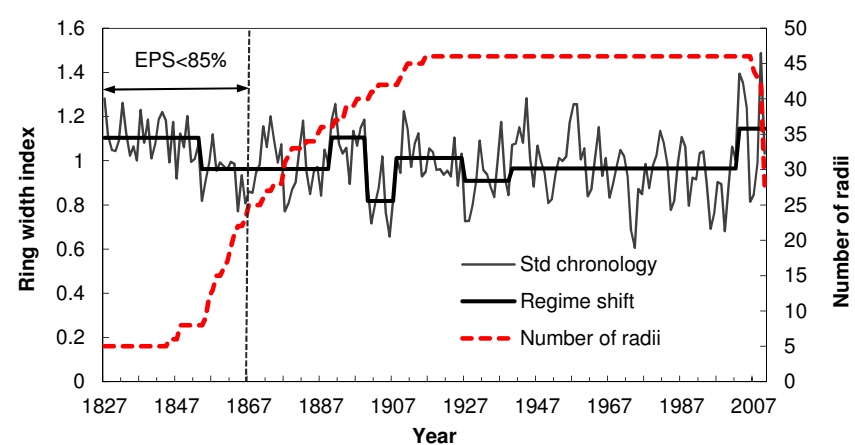

Figure 5. Tree-ring standard chronology of Abies spectabilis from the Kalchuman Lake area of Manaslu, central Nepal.

value of mean sensitivity and standard deviation is 0.136 and 0.18 , respectively. The mean series correlation within tree was high (0.467) as compared to the mean correlation between tree (0.192) and among all radii (0.196). The EPS, an indication of how well the site chronology estimates the population chronology, was above (0.918) the threshold limit of 0.85 (Wigley et al., 1984). The signal-to-noise ratio was 11.23 and the percentage of variance explained by the first eigenvector was $24.4 \%$.

\subsection{Response of tree growth and regeneration to climate change}

The radial growth of the Abies spectabilis at the studied treeline was limited by the low temperature with a positive correlation between the ring width chronology and monthly maximum temperature in most of the month and a negative relationship with minimum temperature (Fig. 6a). The radial growth in A. spectabilis correlated negatively with the mean and minimum monthly temperature of June-September $(r>$ $-0.45, P<0.01$ ) months of the current year (Fig. 6a). However, above-average monthly mean and minimum temperature in the previous year growing period (i.e. JuneSeptember) influence negatively the current year growth. Looking at the influence of seasonal climate on the growth, effect of monsoon season (JJAS) temperature on the growth was stronger than individual counterpart months with a significant negative correlation with seasonal mean $(r=-0.58$, $P<0.01)$ and minimum $(r=-0.66, P<0.01)$ temperature.

Though weak, radial growth was negatively correlated with monthly precipitation of most months of the current year (Fig. 6a). The relationship between ring width and precipitation of February of the current year was slightly negative $(r=-0.38, P<0.05)$. The precipitation during the previous year June correlated positively $(r=0.45, P<0.05)$ with current year growth. The correlation between the radial growth and seasonal sum of precipitation was weak and not significant statistically.
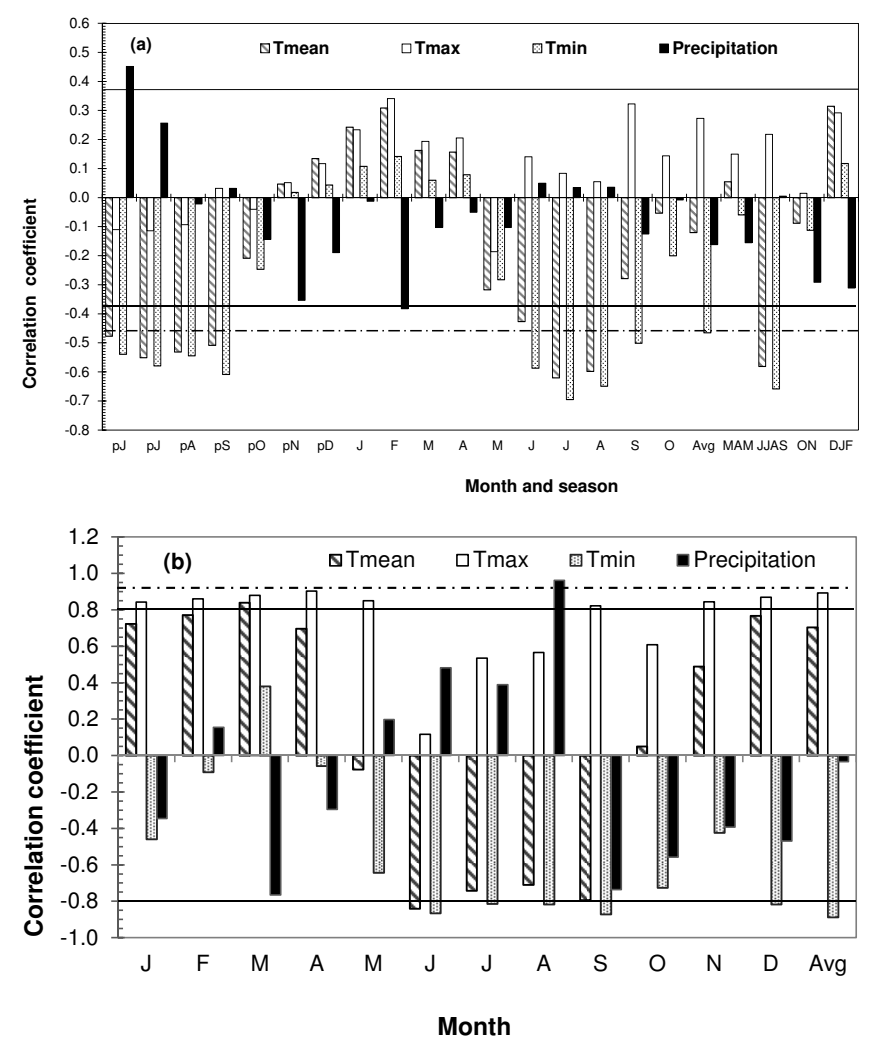

Figure 6. Relationship between the Abies spectabilis' radial growth with climate data (monthly mean, maximum, minimum, seasonal average temperature, and monthly and seasonal sum of precipitation) (a), and relationship between regeneration A. spectabilis with monthly climate (b); the black horizontal line indicates a significant correlation at the $95 \%$ confidence limit for a two-tailed test and dashed horizontal line indicates a significant correlation at the $99 \%$ confidence limit for a two-tailed test. (a) shows the response of radial growth to the monthly climate of June in the previous year to October of the current year as well as seasonal averages. $\mathrm{pJ}$-pD signify June-December of the previous year; MAM, JJAS, $\mathrm{ON}$ and DJF are the mean temperature and the sum of precipitation of March-May, June-September, October-November and previous year December to the current year February, respectively. For climatic influence on the regeneration of the A. spectabilis a climatic window of 12 months of current years as well as annual average of temperature or annual sum of precipitation are used.

Regeneration of the A. spectabilis was favoured positively by the above-average monthly maximum temperature during most of the months and above-average precipitation during dry warm summer months (Fig. 6b). The relationship between regeneration and monthly maximum temperature of the most of the months of the current year was positive and statistically significant $(r>0.8, P<0.05)$ while the relationship was negative but significant with the monthly minimum temperature of June-September of the current year $(r>-0.7, P<0.05)$ (Fig. 6b). The relation 
between regeneration and precipitation in August ( $r=0.96$, $P<0.01$ ) was positive and statistically significant (Fig. 6b).

It is also evident from Fig. $6 \mathrm{a}$ and $\mathrm{b}$ that the growth and regeneration of $A$. spectabilis is more sensitive to minimum or maximum temperature rather than average temperature because correlation with these is more positive or negative than average.

\section{Discussion}

\subsection{Position, structure and dynamics of treeline}

The position and dynamics of the treeline are the result of the interaction of several factors including topoclimate (radiation, temperature, precipitation, length of growing season, and snow cover), topography (slope inclination, relief forms), ecology of tree species (regeneration, seed dispersal, successional stage), site history (climate oscillations, fire, human impact, insect attacks), current biotic (browsing, trampling, diseases and insect pests) and anthropogenic influences (burning, logging, grazing, recreation and tourism) (Holtmeier, 2009). The position of the treeline, species line and species composition varies across the globe as well as at sites within the region (Körner, 1998; Miehe et al., 2007).

In Nepal, the position of the treeline varies between the eastern, central and western region (Schickhoff, 2005). Regardless of the plots, the $A$. spectabilis treeline in the present study was found at $3907 \mathrm{ma.s.1}$. and the B. utilis treeline at $4003 \mathrm{~m}$ a.s.1., which is comparable to the other studies (Körner and Paulsen, 2004; Bhuju et al., 2010; Liang et al., 2014). However, along the western slope of Mt Annapurna, the upper timberline (B. utilis, $R$. campanulatum) at north-facing slopes ascends to $4000-4100 \mathrm{~m}$ a.s.l. and to even $4400 \mathrm{~m}$ a.s.1. on the Nilgiri northern slope (Schickhoff, 2005). Bhuju et al. (2010) found the treeline at $4050 \mathrm{~m}$ a.s.1. in Pangboche of Sagarmatha (Everest) region in eastern Nepal, while at the Lauribina of Langtang in central Nepal it was observed at about $3900 \mathrm{~m}$ a.s.l. (Gaire et al., 2011). Generally, the upper treeline elevations in the Hindu KushKarakoram-Himalaya (HKH) region increases along two gradients: a NW-SE gradient (corresponding to higher temperature sums at the same elevations along the mountain arc) and a peripheral-central gradient from the Himalayan southern slope to the Great Himalayan range and the Tibetan highlands (related to the combined effects of continentality and mass elevation both leading to higher temperature sums) (Schickhoff, 2005).

The size class distribution of the tree species reflects its regeneration status ( $\mathrm{Lv}$ and Zhang, 2012). In our study, the structural parameters of the studied species not only varied between the plots but also between the species. Compared to $\mathrm{T} 1$, the smaller maximum $\mathrm{DBH}$ and younger age of both the A. spectabilis and B. utilis in T2 indicated some influence of the Kalchuman Lake in the seed dispersal in the T2 from downside seed source. The DBH class distribution of $A$. spectabilis shows a bimodal distribution in $\mathrm{T} 1$ with peaks in lower and intermediate DBH classes. The peak in low $\mathrm{DBH}$ class indicates that regeneration in recent years is good. The DBH distribution of B. utilis indicated poor regeneration during recent years. The age distribution was an inverse-J-shaped to multimodal bell-shaped with intra and inter-species differences. Such kind of differences in the age and DBH class distribution of $A$. spectabilis and $B$. utilis have been observed in the other treeline ecotones of Nepal (Shrestha et al., 2007; Bhuju et al., 2010; Suwal, 2010; Gaire et al., 2011), indicating site- and speciesspecific regeneration condition in the Nepal Himalaya. Similarly at the A. spectabilis treeline near the Everest region on the Tibetan side, Lv and Zhang (2012) observed a multimodal age distribution with peaks during 1840-1860 and in recent years. The differential spatio-temporal regeneration pattern reflected in the multimodal size (age and/or DBH) class distributions were also observed in various treeline sites of different mountains: for example Picea schrenkiana in central Tianshan mountains, NW China (Wang et al., 2006), Juniperus przewalskii in the Qilian Mountains, NE Tibetan Plateau (Gou et al., 2012), Pinus uncinata in the Pyrenees Mountains, NE Spain (Camarero and Gutiérrez, 2007; Batllori and Gutiérrez, 2008), Picea glauca in SW Yukon, Canada (Danby and Hik, 2007), Larix gmelinii in the Putorana Mountains, northern Siberia (Kirdyanov et al., 2012), Picea glauca, Picea mariana and Larix laricina, Abies lasiocarpa near Churchill, Manitoba, Canada (Mamet and Kershaw, 2012).

Recruitment, critical determinant of the rate of forest or treeline shift (Camarero and Gutiérrez, 2007), has been found to be more sensitive to climate than adult mortality in harsh environments where competition is low, because recruitment has lower climatic thresholds than adult mortality (Lloyd, 1997). The recruitment of $A$. spectabilis was high during the 1940-1950s and after the 1980s which might have been facilitated by the warm winter temperature in the area and in the country (Cook et al., 2003; Sano et al., 2005). In the present study, the establishment of $A$. spectabilis was high in recent decades as compared to the previous decades, which is consistent to the findings of other studies in the treeline in the Himalaya and other mountains (e.g. Gaire et al., 2011; Batllori and Gutiérrez, 2008; Liang et al., 2011; Lv and Zhang, 2012). Lv and Zhang (2012) found a significant tree recruitment in the recent three decades and sporadic recruitment in earlier periods AD 1760-1960 in the treeline of the Tibetan side of the Everest region. Liang et al. (2011) also found an increased recruitment of Smith fir (Abies georgei) after the 1950 s with an abrupt increase in the 1970s in the Tibetan mountains. Batllori and Gutiérrez (2008) also observed past and recent synchronous recruitment trends of Pinus uncinata with climate change at the treelines in the Iberian eastern range of the Pyrenees. 
The regeneration at the treeline can be sporadic or episodic (Cuevas, 2002; Lv and Zhang, 2012). Patchy spatial distribution of $A$. spectabilis, with gaps in some diameter and age classes observed in the present study, indicates episodic regeneration. The dominance of multimodal age distributions also observed in other alpine or forest-tundra ecotone studies suggested that recruitment in treeline forest ecosystems is episodic or sporadic rather than gradual (Szeicz and MacDonald, 1995; Cuevas, 2002; Batllori and Gutiérrez, 2008; Lv and Zhang, 2012). The spatial distribution of B. utilis was more regular compared to A. spectabilis. In this study, establishment of $B$. utilis in recent decades has been very poor as compared to previous decades. A similar trend has been reported from other treeline sites (e.g. Bhuju et al., 2010). Recruitment of the species was slow in the beginning in both transects and increased gradually to reach at peak in the 1880s in T1 and the 1930s in T2 with a slight oscillation between the 1880 s and 1940s. Similarly, the regeneration of $B$. utilis before the arrival of $A$. spectabilis was high. The maximum age of $B$. utilis was higher than Rhododendron campanulatum (Prabina Rana, personal communication, 2013) and the maximum age of $R$. campanulatum was higher than that of $A$. spectabilis. Hence, this area might have been colonized by shade intolerant $B$. utilis trees followed by shade tolerant understory tree $R$. campanulatum and was later invaded by $A$. spectabilis trees.

Seedling establishment is an important factor dictating the altitudinal limits of treeline species (Hughes et al., 2009). Evidently, treeline rise depends on seeds produced at the local treeline rather than propagulae from more distant sources at lower elevations (Kullman, 2007). At and above the treeline in the study site in the Kalchuman Lake area, we observed neither long-living krummholz nor sub-fossil wood of A. spectabilis and B. utilis. Matured and young seedlings of A. spectabilis and matured Betula were mostly dominant in the lower elevation. However, some seedlings of A. spectabilis, probably due to global warming, have been thriving at much higher elevation than tree individuals. This study indicated both stand densification and upward migration as recorded in many other areas (Camarero and Gutiérrez, 2004; Danby and Hik, 2007; Gehrig-Fasel et al., 2007; Kullman, 2007; Vittoz et al., 2008; Batllori and Gutiérrez, 2008; Kullman and Öberg, 2009; Kirdyanov et al., 2012).

Consistent with the observed trend in the other treelines (Kullman, 2001, 2002; Wang et al., 2006; Kullman and Öberg, 2009; Gou et al., 2012), spatio-temporal age distribution showed that there was regeneration as well as upward migration of the B. utilis until the end of the 1960s though the exact rate is not calculated. The peak in the tree establishment in the past corresponds to the warm episode in both winter and summer reconstructed temperature in the country (Cook et al., 2003). However, we observed a stagnant upper distribution limit or treeline of $B$. utilis in the recent decades along with poor regeneration in spite of temperature warming in the area.
Average upward shifting of the upper distribution limit of A. spectabilis at the treeline ecotone was about $2.61 \mathrm{~m} \mathrm{year}^{-1}$ with some local variation in the area. This upward migration trend of $A$. spectabilis is consistent with the upward migration ( $34 \mathrm{~m}$ per decade) of A. spectabilis in the treeline of the Samagaun region of the MCA (Suwal, 2010), and of Pinus wallichiana (19 and $14 \mathrm{~m}$ per decade on southand north-facing slope) in the western Himalayas (Dubey et al., 2003). Several other studies have reported treeline shifting in different regions of the world (e.g. Camarero and Gutiérrez, 2004; Danby and Hik, 2007; Gehrig-Fasel et al., 2007; Harsch et al., 2009; Kullman 2001, 2002; Kullman and Öberg, 2009; Chauchard et al., 2010; Leonelli et al., 2011; Mamet and Kershaw, 2012; Kirdyanov et al., 2012). Kullman and Öberg (2009) presented a regional-scale treeline rise of Betula pubescens ssp. czerepanovii, Picea abies and Pinus sylvestris in the southern Swedish Scandes of 70-90 m on average with maximum up-shifts of about $200 \mathrm{~m}$ since around AD 1915. Danby and Hik (2007) found an increased tree density as well as an advancement of Spruce (Picea glauca) treeline elevation by $65-85 \mathrm{~m}$ on south-facing slopes in southwest Yukon, Canada during the early to mid-20th century. Similarly, Kirdyanov et al. (2012) observed an upslope shift of the Larix gmelinii treeline position by approximately 30$50 \mathrm{~m}$ in altitude in the Putorana Mountains, northern Siberia during the last century. However, Liang et al. (2011) found no significant upward movement in fir treelines in the Tibetan Plateau despite the warming in the region in the past 200 years.

\subsection{Climatic factors affecting tree growth and regeneration dynamics}

Growth of a tree is associated with several abiotic factors including climate (Fritts, 1976). The radial growth of A. spectabilis fluctuated over time with changing climate and we did not observe constant increment or decrement in the growth. However, a few studies have reported enhanced radial growth of the western Himalayan conifer during recent years (e.g. Borgaonkar et al., 2011).

The radial growth of $A$. spectabilis in the treeline is more responsive to temperature change. Tree growth was positively correlated with temperature $\left(T_{\text {mean }}, T_{\max }\right.$ and $\left.T_{\min }\right)$ from October of the previous year to April of the current year which indicates that temperature before the growing season has a main influence on the radial growth during the subsequent growing period. High winter temperature may induce early melting of snow with the easy availability of melt water for growth in the growing season. Studies also have reported that monthly and seasonal winter temperatures are more limiting than growing-season temperatures to annual radial growth in many upper treeline sites with a positive relationship with winter temperature (Bräuning, 2004; Pederson et al., 2004; Borgaonkar et al., 2011). Bräuning (2004) found a strong positive relationship between the A. spectabilis ring 
width chronology and temperature from November of the previous year to January of the current year in western Nepal. Borgaonkar et al. (2011) found a strong positive relationship between the mean annual and winter (DJF) temperatures of the concurrent year and growth of western Himalayan conifers. The negative relationship, observed in the present study, with the pre-monsoon (MAM) and monsoon season (JJAS) temperature points towards some threshold temperature or moisture stress because increase in temperature in the pre-monsoon and monsoon season without adequate rainfall increases the evapotranspiration which leads to a soilmoisture deficit and limits tree growth (Fritts, 1976; Cook et al., 2003; Yadav et al., 2004). Other studies from the Nepal Himalaya revealed that tree-ring width of A. spectabilis is controlled by pre-monsoon (March-May) climate with negative correlation with temperature and positive correlation with precipitation indicating that moisture availability in this season limits tree growth (Cook et al., 2003; Sano et al., 2005; Chhetri and Thapa, 2010; Gaire et al., 2011). Most of these studies were carried out in the areas much lower than treeline ecotone. Similarly, Yadav et al. (2004) obtained a negative as well as weakened relationship between the mean temperature of the summer months and growth of A. spectabilis from treeline sites of the western Himalaya. In the present study, responses of radial growth of A. spectabilis to minimum and maximum temperatures in the current year were in the opposite direction. This indicated to the prevalence of threshold temperature above or below which the responses become less sensitive to temperature or nonlinear to inverted U-shaped relationship (Paulsen et al., 2000; D’Arrigo et al., 2004; Yadav et al., 2004; Kullman, 2007).

In this study, the radial growth of A. spectabilis was less strongly correlated with precipitation, having significant negative correlation only with February precipitation. As precipitation in these months falls in the form of snow, high snow accumulation delays the growth initiation, shortening the growth period and ultimately resulting in the formation of a narrow ring. A deep snow pack in late winter has been shown to effectively reduce radial growth rates by maintaining low soil temperatures and delaying initiation of cambial expansion (Fritts, 1976; Pederson et al., 2004). Above-average moisture during the June of the previous year positively affects the current year's growth because aboveaverage moisture during summer and early autumn may promote storage of carbohydrates and bud formation, thus enhancing growth during the following year (D'Arrigo et al., 2001; Fritts, 1976). The weak correlation of A. spectabilis radial growth with the precipitation also might be due to its sensitivity to temperature compared to precipitation. Conversely the weak correlation could be due to variation in the precipitation between the sampling sites and the local stations because in the Himalaya precipitation fluctuates greatly, even within a small geographic area (Barros et al., 2004).

The relationship between regeneration of $A$. spectabilis and the monthly maximum temperature of January-
December of the current year was positive while the relation was negative with the monthly minimum temperature of the current year, indicating that low temperature adversely affects seedling survival. Severe soil frosts during cold winters were considered to be critical factors in the control of seedling survival by causing needle and shoot desiccation or fine-root mortality (Körner, 2003; Pederson et al., 2004; Kullman, 2007). Since extremely low cool-season temperatures facilitate the formation of abrasive ice crystals that physically damage trees and as a result often limit establishment at the treeline, this research also supports other recent studies documenting the critical impact of warmer winter temperatures on increased tree establishment in the highelevation ecotones (Kullman, 2007; Kullman and Öberg, 2009; Harsch et al., 2009). The regeneration of A. spectabilis was positively correlated with the precipitation of MayAugust months. The positive relationship with the precipitation of these summer months implies that as the temperature had already attained the minimum threshold required for growth, high rainfall aids the survival and growth of seedlings and saplings. During summer months the temperature in the study area would often be high. So, low rainfall may create a desiccation situation and will have a stronger effect on recruitment because germinants are more sensitive to drought stress (Hughes et al., 2009; Fajardo and McIntire, 2012). Comparing with the past long-term reconstructed climatic data (Cook et al., 2003), the regeneration of Abies seems to be good during the episode of warm winter and cool summer. Hence, temperature plays a crucial role in growth and regeneration of A. spectabilis at the natural climatic treeline of the Himalaya.

From a similar study at the timberline on the Tibetan side of the Everest region, Lv and Zhang (2012) found that A. spectabilis recruitments in 5-year classes were positively correlated with their corresponding monthly mean air temperatures in June and September and with Palmer Drought Severity Index in June. The relationship was inverse for regeneration and ring width. From a study in a treeline on the southeastern Tibetan Plateau, Liang et al. (2011) found a significant positive correlation between the Smith fir (Abies georgei var. smithii) recruitment and both summer and winter temperatures. Wang et al. (2006) reported that several consecutive years of high minimum summer temperature and spring precipitation was the main factors favouring the establishment of Picea schrenkiana following germination within the treeline ecotone in the central Tianshan mountains.

Due to the lack of young seedlings and saplings as well as long climatic data, we could not calculate the climatic variables limiting growth and regeneration of $B$. utilis. However, in a recent study in birch timberlines from the Nepal Himalaya including our study site, Liang et al. (2014) using CRU grid-based data found a significant positive relationship between tree-ring width chronologies of $B$. utilis and precipitation in May and the pre-monsoon (MAM) season and a less strong negative relationship with temperature. They 
concluded that Himalayan birch growth at the upper timberlines is persistently limited by moisture availability during the pre-monsoon season. The poor regeneration and lack of recent shifting of the $B$. utilis in the area might result from the increasing moisture stress (Liang et al., 2014) as available precipitation data from the nearby station have shown a decreasing trend in the precipitation. In addition to the influence of climate change, the lack of recent regeneration of the B. utilis seedlings could be due to the influence of increased canopy cover by its own and associated tree species as well as dense shrub scrub because $B$. utilis seedlings could not establish under their own closed canopy even if they produce viable seeds (Shrestha et al., 2007) because the birch seedling growth is facilitated by direct sunlight (Shrestha et al., 2007; Hughes et al., 2009).

\subsection{Treeline dynamics with climate change}

The relationships between regeneration, treeline shifts and climate change may be more complex because climate may affect tree recruitment and treeline advance rate in different ways (Camarero and Gutiérrez, 2004; Wang et al., 2006; Kirdyanov et al., 2012). A treeline ascent implies several consecutive processes: production of viable seeds, dispersal, availability of adequate regeneration sites, germination, seedling survival and persistence until the individual reaches adulthood (Wang et al., 2006; Kullman, 2007). Climate variability affects all these sequential stages, but the same climatic variable can enhance one of these processes while inhibiting another one (Camarero and Gutiérrez, 2004; Wang et al., 2006). At a global scale, treelines are considered to be constrained primarily by growing season temperature (Körner and Paulsen, 2004). However, at many alpine treeline ecotones, both winter and summer temperatures are often key constraints on tree recruitment (Harsch et al., 2009; Liang et al., 2011) including other local site conditions, species' traits and feedback effects (Danby and Hik, 2007; Batllori and Gutiérrez, 2008). In the present alpine treeline study the establishment of the A. spectabilis is also controlled by both winter and summer climatic events.

An increasing number of studies have demonstrated that tree population density at treelines can respond quickly to rising temperatures (Camarero and Gutiérrez, 2004; Kullman, 2007; Liang et al., 2011) compared to the changes in treeline position because of the great longevity and phenotypic plasticity of tree individuals (MacDonald et al., 1998; Lloyd, 2005). If temperature is the primary and dominant driver for both recruitment and growth, these processes should be positively synchronized (Fajardo and McIntire, 2012). Some previous studies at treelines found concurrent synchronies (MacDonald et al., 1998; Batllori and Gutiérrez, 2008) and lagged synchronies of tree growth and regeneration in both positive and negative directions with climate change (Fajardo and McIntire, 2012). We found a synchronous regeneration of A. spectabilis in the treeline ecotone with climate warming. The climatic conditions that enhance radial growth of $A$. spectabilis were almost similar to the climatic conditions that enhance regeneration with slight variation in some months, which is similar to the findings of other studies (Szeicz and MacDonald, 1995; Camarero and Gutiérrez, 1999). In this study both the recruitment and radial growth of A. spectabilis was found to be associated positively with winter temperature and negatively with summer (May-August) months' mean and minimum temperature.

In spite of the regeneration of A. spectabilis above the existing treeline, the pace of future treeline shifting with climate change may not necessarily be the same because a seedling takes many years from establishment to reach its tree height (in the treeline, Abies took more than 30 years to reach $2 \mathrm{~m}$ height) and then to develop into a forest stand (Lloyd, 2005). On the other hand, there are no seedlings of $B$. utilis in and above the treeline. It will take several decades for newly established Betula seedlings to develop and form a treeline even if they establish now. As A. spectabilis in the treeline is more responsive to temperature change, an advance of this at the natural treeline of the Himalaya with climate change may continue if a long-term warming trend stimulates growth frequently enough even in cooler years or if low temperature events/periods which limit growth and regeneration are insignificant or if there would not be water deficit in plants which could offset the expected positive effects from temperature increase in tree establishment, growth and the upslope advance of treeline (Paulsen et al., 2000; Daniels and Veblen, 2004; Wang et al., 2006; Kullman and Öberg, 2009). In the case of B. utilis, Liang et al. (2014) reported that the birch treeline of the Himalaya is a rare case of a drought-induced alpine timberline and Himalayan birch at its upper distribution boundary is increasingly at risk of survival. Therefore, downslope range shift may occur as a response to global-change-type droughts (Liang et al., 2014). With the supportive evidence of differential life history, regeneration condition and the species-specific response of these two treeline species to climate change, it is clear that, in addition to treeline position, the community structure in the studied treeline in the Himalaya is going to change, if current climate change and response pattern continues.

\section{Conclusions}

The present study provided a recruitment pattern and dynamics history of Himalayan fir and Mountain birch at the highaltitude treeline of the Manaslu region, central Nepal Himalaya. Although regeneration patterns varied between the species, increasing trends of stand densification as well as upward shifting of the studied treeline is evident. The upward shift of A. spectabilis at MCA was estimated to be $2.61 \mathrm{~m}$ year $^{-1}$. In spite of upward migration of $B$. utilis up to the mid-20th century, its upper distribution limit has been stagnant in recent years. The regeneration of A. spectabilis 
was positively related with monthly maximum temperature in most of the months of the current year and precipitation in May-August although the growth of the B. utilis can be also limited by pre-monsoon precipitation (Liang et al., 2014). Spatial and temporal variations in age structure and regeneration pattern of these two species and their species-specific response to climate indicated that the plant communities at the treeline ecotone in the Nepal Himalaya were sensitive to climate change and the studied treeline is changing. Studies incorporating multiple species and covering other proxy evidence like pollen from lake sediments could enhance our understanding of spatio-temporal treeline and vegetation dynamics in association with climate change.

\section{The Supplement related to this article is available online at doi:10.5194/cp-10-1277-2014-supplement.}

Acknowledgements. NAST provided a PhD fellowship to the first author. We are grateful to the National Trust for Nature Conservation for the permission to conduct this study at MCA. We thank Arbindra Shrestha, Janardan Mainali and local field assistants for their help during field work. Amalava Bhattarcharyya, Moinuddin Ahmed, Kumar Mainali and Madan Krishna Suwal provided with valuable suggestions in improving the paper and plotting the figures. Russell E. Train Education for Nature Programme, WWFUS provided a professional grant to the first author to participate in dendrochronology training in China. APN and PAGES supported participation in the PAGES Goa 2013 meetings. We are grateful to the four anonymous reviewers, Thorsten Kiefer and Anne-Laure Daniau for their constructive comments.

Edited by: A.-L. Daniau

\section{References}

Bajaracharya, S. M., Mool, P. K., and Shrestha, B. R.: Impacts of climate change on Himalayan glaciers and glacial lakes: case studies on GLOF and associated hazard in Nepal and Bhutan, ICIMOD and UNEP, Kathmandu, 2007.

Barros, A. P., Kim, G., Williams, E., and Nesbitt, S. W.: Probing orographic controls in the Himalayas during the monsoon using satellite imagery, Nat. Hazards Earth Syst. Sci., 4, 29-51, doi:10.5194/nhess-4-29-2004, 2004.

Batllori, E. and Gutiérrez, E.: Regional tree line dynamics in response to global change in the Pyrenees, J. Ecology, 96, 12751288, doi:10.1111/j.1365-2745.2008.01429.x, 2008.

Becker, A., Korner, C., Brun, J. J., Gusian, A., and Tappeiner, U.: Ecological and land use studies along elevational gradients, Mt. Res. Dev., 27, 59-65, 2007.

Bhattacharyya, A., Lamarche, V. C. J., and Hughes, M. K.: Tree ring chronologies from Nepal, Tree Ring Bulletin, 52, 59-66, 1992.

Bhuju, D. R., Carrer, M., Gaire, N. P., Soraruf, L., Riondato, R., Salerno, F., and Maharjan, S. R.: Dendroecological study of high altitude forest at Sagarmatha National Park, Nepal, in: Contemporary research in Sagarmatha (Mt. Everest) region, Nepal, edited by: Jha, P. K. and Khanal, I. P., Nepal Academy of Science and Technology, Lalitpur, 119-130, 2010.

Bolch, T., Kulkarni, A., Kääb, A., Huggel, C., Paul, F., Cogley, J. G., Frey, H., Kargel, J. S., Fujita, K., Scheel, M., Bajracharya, S., and Stoffe, M.: The state and fate of Himalayan glaciers, Science, 336, 310-314, doi:10.1126/science.1215828, 2012.

Borgaonkar, H. P., Sikder, A. B., and Ram, S.: High altitude forest sensitivity to the recent warming: A tree-ring analysis of conifers from Western Himalaya, India, Quatern. Int., 236, 158166, 2011.

Bradley, R. S. and Jones, P. D.: Little Ice Age' summer temperature variations: their nature and relevance to recent global warming trends, Holocene, 3, 367-376, 1993.

Bräuning, A.: Tree-ring studies in the Dolpo-Himalya (western Nepal), TRACE - Tree Rings in Archaeology, Climatology and Ecology, 2, 8-12, 2004.

Camarero, J. J. and Gutiérrez, E.: Structure and recent recruitment at alpine forest-pasture ecotones in the Spanish central Pyrenees, Ecoscience, 6, 451-464, 1999.

Camarero, J. J. and Gutiérrez, E.: Pace and pattern of recent tree line dynamics: response of ecotones to climatic variability in the Spanish Pyrenees, Climatic Change, 63, 181-200, 2004.

Camarero, J. J. and Gutiérrez, E.: Response of Pinus uncinata recruitment to climate warming and changes in grazing pressure in an isolated population of the Iberian System (NE Spain), Arct. Antarct. Alp. Res., 39, 210-217, 2007.

Chauchard, S., Beilhe, F., Denis, N., and Carcaillet, C.: An increase in the upper tree-limit of silver fir (Abies alba Mill.) in the Alps since the mid-20th century: A land-use change phenomenon, Forest Ecol. Manag., 259, 1406-1415, 2010.

Chen, I.-C., Hill, J. K., Ohlemüller, R., Roy, D. B., and Thomas, C. D.: Rapid range shifts of species associated with high levels of climate warming, Science, 333, 1024-1026, doi:10.1126/science.1206432, 2011.

Chhetri, M.: Culture, environment and biodiversity - linkages and adapting strategy of the local inhabitants in Tsum Valley of Manaslu Conservation Area, Nepal, Prakriti, 19-21, 2009.

Chhetri, P. K. and Thapa, S.: Tree ring and climate change in Langtang National Park, central Nepal, Our Nature, 8, 139-143, 2010.

Cook, E. R.: A time series analysis approach to tree-ring standardization, Ph.D. thesis, The University of Arizona, Arizona, USA, 1985.

Cook, E. R.: The decomposition of tree-ring series for environmental studies, Tree-Ring Bulletin, 47, 37-59, 1987.

Cook, E. R., Krusic, P. J., and Jones, P. D.: Dendroclimatic signals in long tree-ring chronologies from the Himalayas of Nepal, Int. J. Climatol., 23, 707-732, 2003.

Cuevas, J. G.: Episodic regeneration at the Nothofagus pumilio alpine timberline in Tierra del Fuego, Chile, J. Ecology, 90, 5260, 2002.

D’Arrigo, R. D., Schuster, W. S. F., Lawrence, D. M., Cook, E. D., and Wiljanen, M.: Climate-growth relationships of eastern hemlock and chestnut oak from Black Rock Forest in the highlands of southeastern New York, Tree-Ring Research, 57, 183-190, 2001.

D’Arrigo, R. D., Kaufmann, R. K., Davi, N., Jacoby, G. C., Laskowski, C., Myneni, R. B., and Cherubini, P.: Thresholds for warming-induced growth decline at elevational tree line in the 
Yukon Territory, Canada, Global Biogeochem. Cy., 18, GB3021, doi:10.1029/2004GB002249, 2004.

Danby, R. K. and Hik, D. S.: Variability, contingency and rapid change in recent subarctic alpine tree line dynamics, J. Ecology, 95, 352-363, doi:10.1111/j.1365-2745.2006.01200.x, 2007.

Daniels, L. D. and Veblen, T. T.: Spatiotemporal influences of climate on altitudinal treeline in northern Patagonia, Ecology, 85, 1284-1296, 2004.

Dawadi, B., Liang, E., Tian, L., Devkota, L. P., and Yao, T.: Premonsoon precipitation signal in tree rings of timberline $\mathrm{Be}$ tula utilis in the central Himalayas, Quatern. Int., 283, 72-77, doi:10.1016/j.quaint.2012.05.039, 2013.

Dubey, B., Yadav, R. R., Singh, J., and Chaturvedi, R.: Upward shift of Himalayan pine in Western Himalaya, India, Current Sci., 85, 1135-1136, 2003.

Fajardo, A. and McIntire, E. J. B.: Reversal of multicentury tree growth improvements and loss of synchrony at mountain tree lines point to changes in key drivers, J. Ecol., 100, 782-794, doi:10.1111/j.1365-2745.2012.01955.x, 2012.

Fritts, H. C.: Tree Rings and Climate, Cambridge University Press, Cambridge, 567 pp., 1976.

Fujita, K., Takeuchi, N., and Seko, K.: Glaciological observations of Yala Glacier in Langtang Valley, Nepal Himalayas, 1994 and 1996, Bulletin of Glacier Research, 16, 75-81, 1998.

Fukui, K., Fujii, Y., Ageta, Y., and Asahi, K.: Changes in the lower limit of Mountain permafrost between 1973 and 2004 in the Khumbu Himal, the Nepal Himalayas, Global Planet. Change, 55, 251-256, 2007.

Gaire, N. P., Dhakal, Y. R., Lekhak, H. C., Bhuju, D. R., and Shah, S. K.: Dynamics of Abies spectabilis in Relation to Climate Change at the Treeline Ecotone in Langtang National Park, Nepal Journal of Science and Technology, 12, 220-229, 2011.

Gehrig-Fasel, J., Guisan, A., and Zimmermann, N. E.: Tree line shifts in the Swiss Alps: Climate change or land abandonment?, J. Veg. Sci., 18, 571-582, 2007.

Ghimire, S. K., Sapkota, I. B., Oli, B. R., and Prajuli, R. R.: Non timber forest products of Nepal Himalaya, WWF Nepal, Kathmandu Nepal, 2008.

Gottfried, M., Pauli, H., Futschik, A., Akhalkatsi, M., Barančok, P., Alonso, J. L. B., Coldea, G., Dick, J., Erschbamer, B., Calzado, M. R. F., Kazakis, G., Krajči, J., Larsson, P., Mallaun, M., Michelsen, O., Moiseev, D., Moiseev, P., Molau, U., Merzouki, A., Nagy, L., Nakhutsrishvili, G., Pedersen, B., Pelino, G., Puscas, M., Rossi, G., Stanisci, A., Theurillat, J. P., Tomaselli, M., Villar, L., Vittoz, P., Vogiatzakis, I., and Grabherr, G.: Continentwide response of mountain vegetation to climate change, Nature Climate Change, 2, 111-115, doi:10.1038/nclimate1329, 2012.

Gou, X., Zhang, F., Yang Deng, Ettl, G. J., Yang, M., Gao, L., and Fang, K.: Patterns and dynamics of tree-line response to climate change in the eastern Qilian Mountains, northwestern China, Dendrochronologia, 30 121-126, doi:10.1016/j.dendro.2011.05.002, 2012.

Harsch, M. A., Hulme, P. E., McGlone, M. S., and Duncan, R. P.: Are treelines advancing? A global meta-analysis of treeline response to climate warming, Ecol. Lett., 12, 1040-1049, doi:10.1111/j.1461-0248.2009.01355.x, 2009.

Holmes, R. L.: Computer assisted quality control in tree ring dating and measuring, Tree-Ring Bulletin, 43, 69-78, 1983.
Holtmeier, F. K.: Mountain timberlines: Ecology, patchiness and dynamics, Springer, Havixbeck, Germany,, 2009.

Hughes, N. M., Johnson, D. M., Akhalkatsi, M., and Abdaladze, O.: Characterizing Betula litwinowii seedling microsites at the alpine-treeline ecotone, central Greater Caucasus Mountains, Georgia, Arct. Antarct. Alpine Res., 41, 112-118, doi:10.1657/1938-4246(08-021)[HUGHES]2.0.CO;2, 2009.

IPCC: Climate change 2007: the physical sciences basis. Summary for policy makers, Geneva: IPCC, 2007.

Kirdyanov, A. V., Hagedorn, F., Knorre, A. A., Fedotova, E. V., Vaganov, E. A., Naurzbaev, M. M., Moiseev, P. A., and Rigling, A.: 20th century treeline advance and vegetation changes along an altitudinal transect in the Putorana Mountains, northern Siberia, Boreas, 41, 56-67, 2012.

Körner, C.: Re-assessment of high elevation tree line positions and their explanation, Oecologia, 115, 445-459, 1998.

Körner, C.: Alpine Plant Life, 2nd Edn., Springer, 2003.

Körner, C. and Paulsen, J.: A world-wide study of high altitude treeline temperatures, J. Biogeogr., 31, 713-732, 2004.

Kullman, L.: Tree-limits and montane forests in the Swedish Scandes: sensitive biomonitors of climate change and variability, Ambio, 27, 312-321, 1998.

Kullman, L.: 20th century climate warming trend and tree-limit rise in the southern Scandes of Sweden, Ambio, 30, 72-80, 2001.

Kullman, L.: Rapid recent range-margin rise of tree and shrub species in the Swedish Scandes, J. Ecol., 90, 68-77, 2002.

Kullman, L.: Tree line population monitoring of Pinus sylvestris in the Swedish Scandes, 1973-2005: implications for tree line theory and climate change ecology, J. Ecol., 95, 41-52, 2007.

Kullman, L. and Öberg, L.: Post-Little Ice Age tree line rise and climate warming in the Swedish Scandes: a landscape ecological perspective, J. Ecol., 97, 415-429, 2009.

Leonelli, G., Pelfini, M., di Cella, U. M., and Garavaglia, V.: Climate warming and the recent treeline shift in the European Alps: the role of geomorphological factors in high-altitude sites, AMBIO, 40, 264-273, doi:10.1007/s13280-010-0096-2, 2011.

Liang, E., Wang, Y., Eckstein, D., and Luo, T.: Little change in the fir tree-line position on the southeastern Tibetan Plateau after 200 years of warming, New Phytol., 190, 760-769, 2011.

Liang, E., Dawadi, B., Pederson, N., and Eckstein, D.: Is the growth of birch at the upper timberline in the Himalayas limited by moisture or by temperature?, Ecology, in press, doi:10.1890/131904.1, 2014.

Lloyd, A. H.: Response of tree-line populations of foxtail pine ( $\mathrm{Pi}$ nus balfouriana) to climate variation over the last 1000 years, Can. J. Forest Res., 27, 936-942, 1997.

Lloyd, A. H.: Ecological histories from Alaskan tree lines provide insight into future change, Ecology, 86, 1687-1695, 2005.

Lv, X. and Zhang, Q. B.: Asynchronous recruitment history of Abies spectabilis along an altitudinal gradient in the Mt. Everest region, J. Plant Ecol., 5, 147-156, 2012.

MacDonald, G. M., Szeicz, J. M., Claricoates, J., and Dale, K. A.: Response of the central Canadian treeline to recent climate changes, Ann. Assoc. Am. Geogr., 88, 183-208, 1998.

Mamet, S. D. and Kershaw, G. P.: Subarctic and alpine tree line dynamics during the last 400 years in north-western and central Canada, J. Biogeogr., 39, 855-868, doi:10.1111/j.13652699.2011.02642.x, 2012. 
Marcott, S. A., Shakun, J. D., Clark, P. U., and Mix, A. C.: A reconstruction of regional and global temperature for the past 11,300 years, Science, 339, 1198-1201, doi:10.1126/science.1228026, 2013.

Miehe, G., Miehe, S., Vogel, J., Co, S., and Duo, L.: Highest treeline in the northern hemisphere found in southern Tibet, Mt. Res. Dev., 27, 169-173, 2007.

PAGES 2k Consortium: Continental-scale temperature variability during the past two millennia, Nature Geosci., 6, 339-346, doi:10.1038/NGEO1797, 2013.

Parmesan, C. and Yohe, G.: A globally coherent fingerprint of climate change impacts across natural systems, Nature, 42, 37-42, 2003.

Parolo, G. and Rossi, G.: Upward migration of vascular plants following a climate warming trend in the Alps, Basic Appl. Ecol., 9, 100-107, 2008.

Pauli, H., Gottfried, M., Dullinger, S., Abdaladze, O., Akhalkatsi, M., Benito Alonso, J. L., Coldea, G., Dick, J., Erschbamer, B., Fernández Calzado, R., Ghosn, D., Holten, J. I., Kanka, R., Kazakis, G., Kollár, J., Larsson, P., Moiseev, P., Moiseev, D., Molau, U., Molero Mesa, J., Nagy, L., Pelino, G., Puscas, M., Rossi, G., Stanisci, A., Syverhuset, A.-O., Theurillat, J. P., Tomaselli, M., Unterluggauer, P., Villar, L., Vittoz, P., and Grabherr, G.: Recent plant diversity changes on Europe's mountain summits, Science, 336, 353-355, doi:10.1126/science.1219033, 2012.

Paulsen, J., Weber, U. M., and Körner, C.: Tree growth near treeline: abrupt or gradual reduction with altitude?, Arct. Antarct. Alp. Res., 32, 14-20, 2000.

Pederson, N., Cook, E. R., Jacoby, G. C., Peteet, D. M., and Griffin, K. L.: The influence of winter temperatures on the annual radial growth of six northern range margin tree species, Dendrochronologia, 22, 7-29, doi:10.1016/j.dendro.2004.09.005, 2004.

Rinn, F.: TSAP-Win Reference Manual, Version 0.53, Rinntech, Heidelberg, 1996.

Rodionov, S. N.: A sequential algorithm for testing climate regime shifts, Geophys. Res. Lett., 31, L09204, doi:10.1029/2004GL019448, 2004.

Rodionov, S. N.: Use of prewhitening in climate regime shift detection, Geophys. Res. Lett., 33, L12707, doi:10.1029/2006GL025904, 2006.

Root, T. L., Price, J. T., Hall, K. R., Schneider, S. H., Rosenzweigk, C., and Pounds, J. A.: Fingerprints of global warming on wild animals and plants, Nature, 421, 57-60, 2003.

Sano, M., Furuta, F., Kobayashi, O., and Sweda, T.: Temperature variations since the mid-18th century for western Nepal, as reconstructed from tree-ring width and density of Abies spectabilis, Dendrochronologia, 23, 83-92, 2005.
Schickhoff, U.: The upper timberline in the Himalayas, Hindu Kush and Karakorum: a review of geographical and ecological aspects, in: Mountain ecosystems: studies in treeline ecology, edited by: Broll, G. and Keplin, B., Springer, Berlin, Germany, 275-354, 2005.

Shrestha, A. B., Wake, C. P., Mayewski, P. A., and Dibb, J. E.: Maximum temperatrure trend in the Himalaya and its vicinity:An analysis based on temperature records from Nepal for period 1971-94, J. Climate, 12, 2775-2787, 1999.

Shrestha, B. B., Ghimire, B., Lekhak, H. D., and Jha, P. K.: Regeneration of tree line Birch (Betula utilis D. Don) forest in transHimalayan dry valley in central Nepal, Mt. Res. Dev., 27, 250258, 2007.

Shrestha, M. L.: Challenging climates: adapting to change, Nepal baseline study, British Council, 100 pp., 2008.

Speer, J. H.: Fundamentals of tree ring research, The University of Arizona Press, Tucson, 2010.

Suwal, M. K.: Tree species line advance of Abies spectabilis in Manaslu Conservation Area, Nepal Himalaya, M.Sc. thesis, Central Department of Botany, Tribhuvan University, Kathmandu, 2010.

Szeicz, J. M. and MacDonald, G. M.: Recent white spruce dynamics at the subarctic alpline tree line of north-western Canada, J. Ecol., 83, 873-885, 1995.

Vittoz, P., Rulence, B., Largey, T., and Freléchoux, F.: Effects of climate and land-use change on the establishment and growth of cembran pine (Pinus cembra L.) over the altitudinal treeline ecotone in the central Swiss Alps, Arct. Antarct. Alp. Res., 40, 225 232, doi:10.1657/1523-0430(06-010)[VITTOZ]2.0.CO;2, 2008.

Wang, T., Zhang, Q.-B., and Ma, K.: Tree line dynamics in relation to climatic variability in the central Tianshan Mountains, northwestern China, Global Ecol. Biogeogr., 15, 406-415, 2006.

Webb, L. B., Whetton, P. H., Bhend, J., Darbyshire, R., Briggs, P. R., and Barlow, E. W. R.: Earlier wine-grape ripening driven by climatic warming and drying and management practices, Nature Climate Change, 2, 259-264, doi:10.1038/NCLIMATE1417, 2012.

Wigley, T. M. L., Briffa, K. R., and Jones, P. D.: The average value of correlated time series with applications in dendroclimatology and hydrometeorology, Int. J. Climatol., 8, 33-54, 1984.

Yadav, R. R., Singh, J., Dubey, B., and Chaturvedi, R.: Varying strength of relationship between temperature and growth of highlevel fir at marginal ecosystems in western Himalaya, India, Current Sci., 86, 1152-1156, 2004.

Yao, T., Thompson, L., Yang, W., Yu, W., Gao, Y., Guo, X., Yang, X., Duan, K., Zhao, H., Xu, B., Pu, J., Lu, A., Xiang, Y., Kattel, D. B., and Joswiak, D.: Different glacier status with atmospheric circulations in Tibetan Plateau and surroundings, Nature Climate Change, 2, 663-667, doi:10.1038/NCLIMATE1580, 2012. 